\title{
Pemanfaatan Google Classroom dalam Penilaian Autentik Studi Kasus SD Negeri Sidomulyo 05 Silo Kabupaten Jember
}

\author{
Ratih Wulandari ${ }^{1)}$, Asri Widiatsih ${ }^{2 *}$, Syamsul Muarif ${ }^{3)}$ \\ 1) SD Negeri 5 Sidomulyo Silo Jember \\ 2,3) IKIP PGRI Jember \\ wulandariratih72@gmail.com, ${ }^{*}$ asriwidiatsih@ikipjember.ac.id, syamsulmuarif702@gmail.com
}

DOI: https://doi.org/10.21107/rekayasa.v13i2.5904

\section{Using of Google Classroom in Authentic Assessment Case Study at SD Sidomulyo 05 Silo, Jember}

\begin{abstract}
This study aims to describe the use of Google Classroom in authentic assessment in class VI of Sidomulyo 05 Silo Public Elementary School, Jember Regency. The focus of this research is how the use of Google Classroom in authentic assessment in class VI SD Negeri Sidomulyo 05 Silo, Jember Regency which is divided into sub-focus as follows: 1) Opening Google Classroom 3) Implementation of Assessment using Google Classroom, 3) Constraints faced in utilization Google Classroom. The approach in this research is qualitative research, with descriptive methods. In comparison, the object of research is Sidomulyo Public Elementary School 05 Silo, Jember Regency. The data collection techniques using observation, interviews, and documentation techniques with data analysis using qualitative data analysis procedures are consisting of: data condensation, data presentation, and conclusion/verification. The results showed that the authentic assessment of Indonesian thematic learning and science could use Google Classroom. Assessment includes attitude assessment by observation and assessment between friends, assessment of knowledge using written, oral, and assignment tests as well as an assessment of skills by evaluating performance, projects, products, portfolio, and discussion skills. The obstacles include the difficulty of students in applying Google classroom because they are not familiar, and the parents of students are given an understanding first.
\end{abstract}

Keywords: Google Classroom, Authentic Assessment, Thematic Learning.

\section{ABSTRAK}

Penelitian ini bertujuan untuk mendeskripsikan pemanfaatan Google Classroom dalam penilaian autentik di kelas VI SD Negeri Sidomulyo 05 Silo Kabupaten Jember. Adapun fokus penelitian ini adalah bagaimana pemanfaatan Google Classroom dalam penilaian autentik di kelas VI SD Negeri Sidomulyo 05 Silo Kabupaten Jember yang dibagi menjadi sub focus sebagai berikut: 1) Membuka Google Classroom 3) Pelaksanaan Penilaian menggunakan Google Classroom, 3) Kendala yang dihadapi dalam pemanfaatan google Classroom. Pendekatan dalam penelitian ini adalah penelitian kualitatif, dengan metode deskriptif. Sedangkan yang menjadi obyek penelitian adalah SD Negeri Sidomulyo 05 Silo Kabupaten Jember. Adapun teknik pengumpulan datanya menggunakan teknik observasi, wawancara, dan dokumentasi dengan analisis data menggunakan prosedur analisis data kualitatif yang terdiri dari: kondensasi data, penyajian data, dan penyimpulan/verifikasi. Hasil penelitian menunjukkan bahwa penilaian autentik pembelajaran tematik Bahasa Indonesia dan IPA dapat menggunakan Google Classroom. Penilaian meliputi penilaian sikap dengan observasi dan penilaian antara teman, penilaian pengetahuan menggunakan tes tulis, lisan dan penugasan serta penilaian ketrampilan dengan melakukan penilaian terhadap kinerja, proyek, produk, fortofolio dan ketrampilan diskusi. Kendalanya antara lain siswa kesulitan dalam mengaplikasikan google classroom karena belum terbiasa dan orang tua siswa harus diberi pemahaman terlebih dahulu.

Kata Kunci: Google Classroom, Penilaian Autentik, Pembelajaran Tematik

\section{PENDAHULUAN}

Salah satu komponen dari pembelajaran adalah penilaian dalam proses pendidikan. Penilaian merupakan proses pengumpulan dan pengolahan informasi untuk mengukur pencapaian hasil belajar peserta didik. Penilaian hasil belajar diperlukan untuk mengukur pencapaian hasil belajar hasil belajar oleh pendidik dengan melalui proses selama

\section{Article History:}

Received: August, 30 ${ }^{\text {th }}$ 2019; Accepted: May, $10^{\text {th }} 2020$

REKAYASA ISSN: 2502-5325 has been Accredited by Ristekdikti (Arjuna) Decree: No. 23/E/KPT/2019 August $8^{\text {th }}$, 2019 effective until 2023 pembelajaran serta kemajuan belajar untuk dilakukan perbaikan secara berkesinambungan. Informasi tentang kelemahan dan kekuatan pembelajaran dan belajar pendidik dan peserta didik dapat dapat diketahui berdasarkan penilaian hasil belajar oleh pendidik. Berdasarkan informasi tersebut maka pendidik memiliki arah yang jelas untuk merefleksi mengenai apa yang harus diperbaiki dan dilakukan dalam

\section{Cite this as:}

Wulandari, R., Widiatsih, A., \& Muarif, S. (2020). Pemanfaatan Google Classroom dalam Penilaian Autentik Studi Kasus SD Negeri Sidomulyo 05 Silo Kabupaten Jember. Rekayasa, 13(2), 187-196. https://doi.org/10.21107/rekayasa.v13i2.5904 
pembelajaran dan belajar (Permendikbud No 104, 2014).

Penelitian (Prastowo, 2017) tentang penerapan pembelajaran tematik menemukan bahwa penyusunan Rencana Pelaksanaan Pembelajaran (RPP) TematikTerpadu merupakan factor kesulitan terbesar. Berdasarkan pendapat (Karli, 2016) bahwa Implementasi Pembelajaran tematik di sekolah dasar maka guru sangat berperan untuk memperhatikan beberapa komponen seperti metode, penilaian, media dan langkah pembelajaran.

Implementasi pembelajaran tematik Kurikulum 2013 untuk SD/MI menurut (Andi, 2015) perlu dibuatkan buku panduan. Berdasarkan penelitian (Puspita, 2016) bahwa perencanaan tematik terpadu yang dilakukan guru sudah memuat kriteria minimal perencanaan pembelajaran, dengan menggunakan pemaduan pelajaran Kompetensi Dasar (KD) mata pelajaran dan setiap KD memiliki materi tersendiri. Menurut (Mulyadin, 2016) bahwa kepala sekolah harus melakukan pengawasan agar proses perencanaan pembelajaran, pelaksanaan pembelajaran, dan penilaian hasil belajar yang dilakukan guru berjalan maksimal.

Standar Penilaian Pendidikan menyatakan bahwa proses pengumpulan dan pengolahan informasi untuk mengukur pencapaian hasil belajar peserta didik mencakup: penilaian autentik, penilaian diri, penilaian berbasis portofolio, ulangan harian, ulangan tengah semester, ulangan akhir semester, ujian tingkat kompetensi, ujian mutu tingkat kompetensi, ujian nasional, ujian sekolah/madrasah merupakan penilaian pendidikan (Permendikbud No.66 Tahun 2013). Penilaian autentik merupakan penilaian yang dilakukan secara komprehensif untuk menilai hasil belajar yang meliputi ranah afektif (sikap), ranah kognitif (pengetahuan), dan ranah psikomotor (keterampilan) mulai dari tahap masukan (input), proses, dan keluaran (output) pembelajaran. Penilaian autentik bersifat alami, apa adanya, tidak dalam suasana tekanan (Munawati, 2017).

Tujuan dilakukannya penilaian autentik adalah (1) prinsip-prinsp penilaian diterapkan dalam perencanaan penilaian peserta didik sesuai dengan kompetensi yang akan dicapai, (2) pelaksanaan penilaian peserta didik secara profesional, terbuka, edukatif, efektif, efisien, dan sesuai dengan konteks sosial budaya; dan (3) pelaporan hasil penilaian peserta didik secara objektif, akuntabel, dan informatif. Pada dasarnya penilaian autentik memiliki makna yang lebih signifikan dibandingkan dengan tes pilihan ganda meskipun telah terstandar sekalipun (Kemendikbud, 2013).

Pelaksanaan penilaian autentik masih banyak mengalami kesulitan. Ada kecenderungan dari para pendidik lebih memilih menggunakan penilaian dalam bentuk tes karena dianggap lebih mudah dan praktis. Masih banyak guru yang belum melaksanakan penilaian autentik dan hanya mengandalkan penilaian yang bersifat tes (pencil and paper test) sehingga penilaian yang bersifat autentik masih kesulitan untuk dilaksanakan (Siswanto, 2015).

Budaya belajar siswa masih berupa budaya belajar mengerjakan soal. Banyak siswa dapat mengerjakan soal untuk sekedar lulus dengan mengesampingkan aspek sikap dan keterampilan. Evaluasi yang seringkali dilakukan sebagai acuan (Tes sumatif, formatif, UN) tidak pernah mengevaluasi aspek keterampilan. Tidaklah mengherankan jika perlahan terbentuk sikap negatif terhadap penguasaan keterampilan dan pembentukan sikap (Widiyantoro, 2016)

Berdasarkan penelitian (Enggarwati, 2015) menunjukkan bahwa kenyataan di lapangan menunjukkan bahwa guru mengalami kesulitan dalam mengimplementasikan penilaian autentik. Kesulitan ini disebabkan karena pemahaman guru tentang penilaian autentik masih kurang. Kurangnya pemahaman ini meliputi tiga aspek yaitu guru, siswa dan waktu. Aspek guru meliputi kreativitas guru masih rendah dan kurangnya pelatihan penilian autentik. Sedangkan aspek siswa berupa karakteristik siswa yang tidak mendukung. Aspek yang ketiga adalah waktu yang tidak mencukupi bagi guru untuk melakukan penilaian autentik. Penelitian (Astriyandi, Chotimah, \& Faisal, 2016) yang menyatakan bahwa kemampuan guru menerapkan penilaian autentik dalam pembelajaran dalam kategori kurang baik. Sependapat dengan hal tersebut penelitian 
(Aiman, 2016) tentang faktor penghambatnya adalah kekurang pemahaman guru tentang proses penilaian autentik dan instrument yang digunakan dalam penilaian autentik. Penelitian (Zuhera, Habibah, \& Mislinawati, 2017) bahwa kesulitan guru dalam memberikan penilaian autentik berdasarkan kurikulum 2013 di SD dalah keterbatasan waktu, jumlah siswa yang banyak dalam satu kelas dan sulitnya mengarahkan siswa untuk menanamkan sikap yang baik sesuai dengan tujuan pembelajaran. Hal ini berarti perlu adanya pelatihan tentang penilaian autentik bagi guru.

Usia anak SD sekarang ini disebut generasi Z (lahir tahun 1998-2009) dan generasi A (lahir setelah tahun 2009) yang banyak memanfaatkan internet dalam keseharian mereka. Ciri-ciri generasi $Z$ dan $A$ memiliki kesamaan yaitu ekspresif, fasih teknologi, dan intens berinteraksi melalui media sosial. Di era digital saat ini, siswa SD sudah terbiasa mengakses internet. Teknologi sudah berdampingan dalam kehidupan masyarakat, sehingga setiap individu tidak dapat mencegah atau menolaknya. Guru seharusnya dapat memanfaatkan teknologi dalam melaksanakan pembelajaran. Perubahan paradigm pembelajaran sangat penting dilakukan oleh guru yang berperan sebagai agen of change. Teknologi dan pendidikan harus sejalan dan tidak dapat dipisahkan.

Gooogle classroom adalah platform pembelajaran campuran yang dikembangkan oleh google untuk keperluan sekolah. Tujuannya adalah untuk membantu mempermudah pembelajaran dengan cara menyederhanakan pembuatan, pendistribusian dan penetapan tugas tanpa menggunakan kertas. Google classroom dapat digunakan melalui komputer dan telepon gengam. Untuk mengunduh aplikasinya makanguru dan siswa dapat membuka situs https://classroom.google.com atau melalui playstore di android atau app store di iOS menggunakan kata kunci google classroom. Penggunaannya gratis atau tanpa biaya sehingga penggunaannya dapat dimanfaatkan oleh guru dan siswa sesuai kebutuhan (Rachmadyanti, 2014).

Inovasi dalam pembelajaran sangat diperlukan saat ini terutama di era global. Dengan harapan bahwa peserta didik dapat memperoleh pembelajaran yang sangat bermakna untuk pembentukan pengetahuan baru atau penyempurnaan dari pengetahuan awal bagi peserta didik.

Kecenderungan karakteristik siswa di era global sekarang ini adalah tidak lagi mengandalkan buku cetak dalam belajar. Bahkan ada kecenderungan bahwa siswa malas untuk membaca buku. Mereka lebih suka menggunakan media digital dalam belajar. Agar sesuai dengan kebutuhan zaman maka guru perlu memahami model pembelajaran yang efektif dan efisien. Guru harus bisa berinovasi dalam pembelajaran berbasis proyek dan mampu menjadikan siswa siap di era digital, berwawasan global, dan mampu berkolaborasi. Untuk hal itu dipandang perlu untuk merancang pembelajaran dan penilaian yang memanfaatkan media digital sebagai sarananya.

Media digital yang digunakan diharapkan juga dapat menjadi solusi untuk keterbatasan waktu belajar di sekolah. Guru dapat menyampaikan materi, memberi petunjuk tugas, memberikan umpan balik, dan penilaian melalui media digital ini. Media digital yang dimaksud adalah aplikasi Google Classroom. Dengan memanfaatkan media google Classroom ini dalam pembelajaran diharapkan guru dapat melakukan penilaian autentik tanpa terkendala oleh ruang dan waktu.

Pemanfaatan google classroom dalam kegiatan pembelajaran maupun sebagai sarana untuk mengumpulkan tugas, dan penilaian guru diharapkan dapat memotivasi peserta didik untuk belajar. Disamping itu google classroom juga dapat mengatasi masalah keterbatasan waktu di sekolah. Aplikasi google classroom ini juga dapat mempermudah guru dalam memberi penilaian.

\section{METODE PENELITIAN}

\section{Pendekatan dan Jenis Penelitian}

Penelitian ini menerapkan pendekatan kualitatif dan rancangan studi kasus. Penelitian ini bertujuan untuk mendeskripsikan bagaimana pemanfaatan Google Classroom untuk penilaian autentik di SD Negeri Sidomulyo 05 Silo Kabupaten Jember. Kecamatan Silo Kabupaten 
Jember adalah lokasi penelitian yang ditetapkan oleh peneliti dimana SD Negeri Sidomulyo 05 berada.

\section{Kehadiran Peneliti}

Peneliti dalam penelitian studi kasus bertindak sebagai instrument kunci yang bertindak sebagai perencana, pengumpul data, penganalisis, penafsir, dan pelapor atas hasil penelitiannya (Bogdan \& Biklen, 2003). Kehadiran peneliti di lapangan sebagai pengamat penuh dan merupakan tolak ukur mendapatkan keabsahan data diharapkan dapat menunjang keberhasilan dalam pemahaman fokus penelitian.

\section{Sumber Data}

Data yang dikumpulkan sendiri oleh peneliti yang didapatkan secara langsung. Pengidentifikasian sumber data dilakukan dengan prinsip snow ball, dimana informasi dari informan pertama akan dijadikan sebagai informasi kunci untuk menentukan informan selanjutnya yang dapat memberikan data penelitian.

\section{Teknik Pengumpulan Data}

Teknik pengumpulan data dalam penelitian ini seperti penelitian studi kasus pada umumnya. Teknik pengumpulan data yang digunakan adalah sebagai berikut: (1) wawancara mendalam, (2) observasi, (3) studi dokumentasi.

\section{Teknik Analisa dan Pengecekan Keabsahan Data}

Menurut (Miles, Huberman, \& Saldana, 2014) analisis data merupakan proses penelaahan, pengurutan, dan pengelompokan data dengan tujuan untuk menyusun proposisi dan menjadikannya sebagai teori sebagai hasil penelitian. Sedangkan menurut (Bogdan \& Biklen, 2003) analisa data merupakan proses mengumpulkan dan menyusun data secara sistematis dari hasil wawancara, catatan lapangan, dan bahan-bahan lain sehingga mudah dipahami dan temuannya dapat disebarluaskan.

Kegiatan analisis data dalam penelitian ini merupakan kegiatan penelaahan dan penyusunan secara sistematik semua transkrip wawancara, catatan lapangan, dan materi penelitian lainnya yang telah direkam peneliti selama pengumpulan data penelitian (Bogdan \& Biklen, 2003). Teknik analisis data yang digunakan adalah teknik analisis induktif (inductive analysis) yang meliputi dua jenis analisis yaitu analisis dalam situs. Analisis dilakukan dengan mengikuti model Miles, Huberman \& Saldana (2014) yaitu analisis data kualitatif yang merupakan tiga alur kegiatan yang terjadi secara bersamaan. Aktivitas dalam analisis data yaitu: Data Condensation, Data Display, dan Conclusion Drawing/Verification.

Ketiga kegiatan tersebut dilakukan secara simultan, dalam artian kegiatan kondensasi data tidak terpisah dengan kegiatan pengumpulan data atau sebaliknya, dan tidak pula terpisah dengan proses pengambilan kesimpulan. Ketiganya dilakukan bersama-sama saat proses pengumpulan data berlangsung.

Keabsahan data dalam penelitian kualitatif meliputi uji credibility (validitas internal), transferability (validitas eksternal), dependability (relabilitas), dan confirmability (obyektivitas). Uji keabsahan data pertama dilakukan melalui pengecekan kredibilitas yang dilakukan dengan teknik trianggulasi metode pengumpulan data, triangulasi sumber data, diskusi teman sejawat, dan pengecekan ulang (member check). Triangulasi metode pengumpulan data dilakukan dengan cara data yang diperoleh dari metode wawancara mendalam, observasi, atau studi dokumentasi saling dicocokkan satu sama lain sehingga diperoleh keakuratan data, sesuai saran Reynolds \& Nasution yang dikutip oleh (Mantja, 2008).

\section{HASIL DAN PEMBAHASAN}

Penelitian ini dilakukan di SD Negeri Sidomulyo 05 Silo Kabuapten Jember kelas VI yang merupakan kelas tinggi. Hal ini disebabkan karena siswa kelas tinggi memiliki minat terhadap kehidupan praktis sehari-hari yang nyata. Siswa kelas tinggi sudah mulai memiliki minat untuk melakukan penelitian, percobaan dan bereksprerimen (Soematri \& Nana Syaodih, 2008). Siswa kelas VI sudah bisa siap menerima perkembangan zaman melalui teknologi yang ada dan menerapkannya. 
Menurut Khikmawati dalam (Ulum, Fantiro, \& Rifa'i, 2019) Google Apps adalah layanan berbasis aplikasi yang diciptakan dibuat oleh google. Guru dapat memanfaatkan Google Apps memungkinkan untuk mengunggah dan mengakses berbagai file seperti video, foto, spreadsheet dan PDF. Google Apps dapat diakses oleh guru dari mana saja yang mempunyai jaringan internet. Kapasitas Google Apps sebesar 5 Gigabite (GB). Google Apps memberikan layanan manajemen dokumen online yang dapat memberi manfaat yang besar untuk dunia pendidikan (Khikmawati, 2014). Google Apps for Education terdiri dari: (1) Gmail, (2) Google Calendar (3) Google Talk, (4) Google Docs, (5) Google Sites, (6) Google Drive, dan (7) Google Classroom yaitu suatu serambi pembelajaran yang dapat membuat dan membagikan serta memilah-milah setiap penugasan tanpa kertas.

Khikmawati dalam (Ulum et al., 2019) dukungan Google Apps memiliki yang dapat dimanfaatkan oleh dunia pendidikan, diantaranya adalah: (1) Untuk proses belajar mengajar. (2) merekam aktivitas siswa, (3) Evaluasi belajar, (4) Kerja tim, (5) merangsang kreativitas siswa, (6) mengolah data, (7) membuat presentasi, (8) membuat spreadsheet, (9) membuat gambar dan (10) membuat google form. Dengan layanan tersebut maka guru merencanakan pembejaran tematik dengan baik dan dapat menyajikan materi pembelajarannya secara online (dan offline) yang mudah diakses siswa. Guru dapat mengunggah file materi pembelajarannya dalam berbagai bentuk dan format seperti dokumen, audio, video, dan sebagainya. Siswa dapat mengunduh melalui smartphone, table dan computer. Dengan smartphone dan tablet yang praktis untuk dibawa kemana saja (portable), lebih terjangkau (harganya) dibanding dengan computer maka akan memberikan kesempatan belajar tanpa batasan ruang, mudah untuk akses informasi melalui nirkabel dan dapat mendorong pengembangan literasi digital, serta memberikan kesempatan belajar dengan bebas (independent learning).

Berdasarkan hasil penelitian maka pemanfaatan google Classroom di SD Negeri Sidomulyo 05 Silo Jember melalui tahap-tahap sebagai berikut:

\section{Membuka Google Classroom}

Untuk membuka goolgle Classroom maka harus mengikuti beberapa langkah sebagai berikut:

a. Langkah pertama adalah Login melalui google untuk pertama kali dengan membuka google classroom dengan mengetik classroom.google.com lalu klik buka classroom

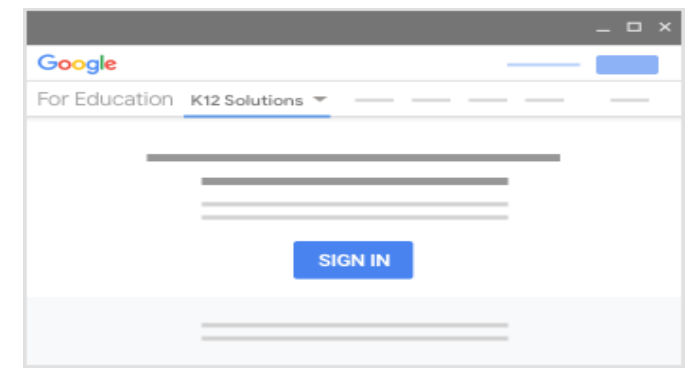

Gambar 1. Tampilan awal Google Classroom

b. Langkah ke-dua yaitu login dengan memasukkan nama pengguna Anda, lalu klik berikutnya.

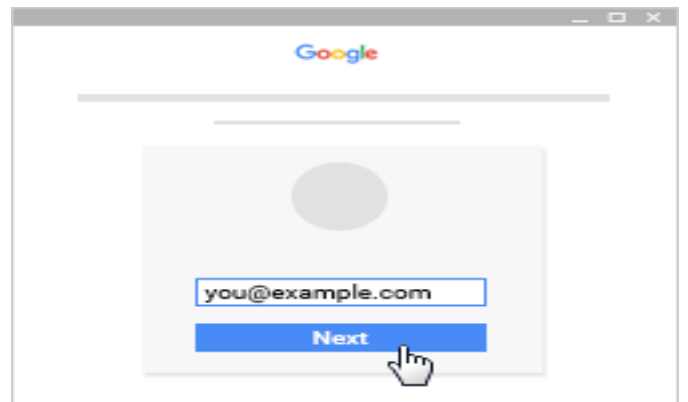

Gambar 2. Tampilan Login Google Classroom

c. Langkah ke-tiga yaitu login dengan memasukkan sandi Anda, lalu klik Masuk

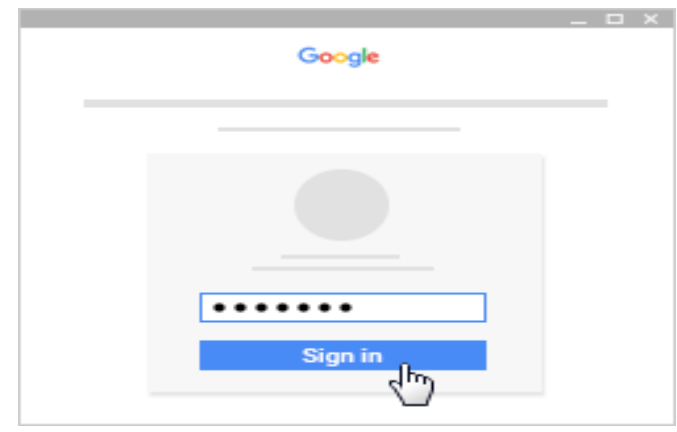

Gambar 3. Tampilan Input Password Google Classroom 
d. Langkah ke-empat login dan jika ada pesan selamat datang, baca pesan tersebut, lalu klik terima

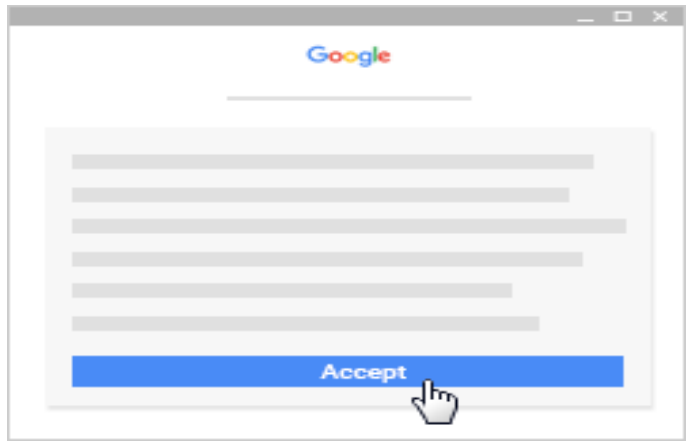

Gambar 4. Tampilan pesan selamat datang setelah login Google Classroom

e. Langkah ke-lima yaitu login untuk memilih sebagai seorang siswa atau pengajar.

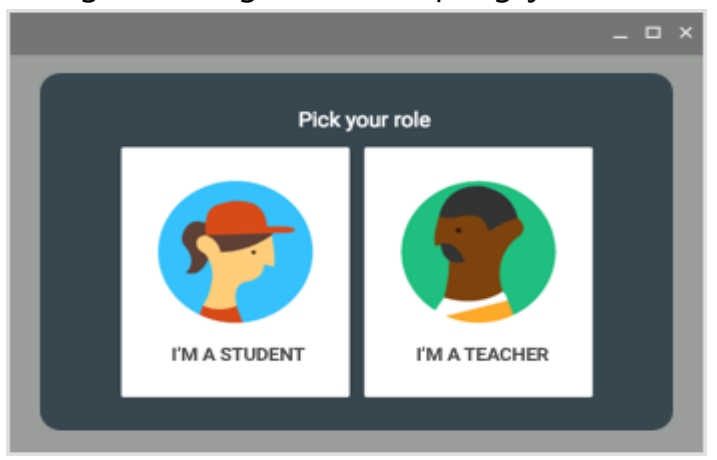

Gambar 5. Tampilan menu pilihan siswa atau pengajar dalam google classroom

f. Langkah ke-enam yaitu memulai menggunakan Google Classroom dengan meng-klik "Mulai"

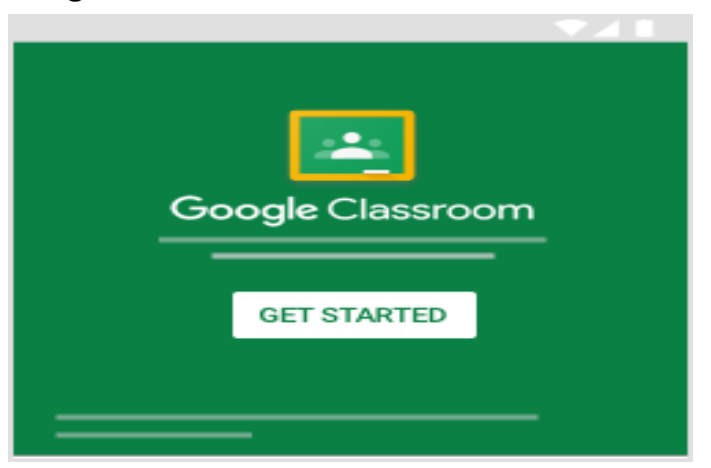

Gambar 6. Tampilan untuk memulai Google Classroom

Dengan langkah-langkah tersebut diatas maka Anda sudah bisa melakukan penilaian autentik karena sudah membuat dan bisa mengelola kelas di Google Classroom.

\section{Pelaksanaan Penilaian menggunakan Google Classroom}

Perencanaan sangat penting dalam proses pembelajaran maka sebelum pembelajaran berlangsung, guru harus menyusun rancangan pembelajaran yang terencana yang dituangkan dalam bentuk skenario pembelajaran atau RPP. Keberhasilan dalam pelaksanaan proses pembelajaran sangat ditentukan oleh perencanaan.

Penyusunan RPP perlu diperhatikan adanya keterkaitan antara Kompetensi Dasar, Tujuan Pembelajaran, Indikator Pembelajaran, Materi Pembelajaran, Pengalaman belajar, dan Penilaian. Rancangan penilaian harus memuat aspek sikap, pengetahuan, dan keterampilan. Rancangan penilaian juga harus terdiri dari penilaian pre tes, proses, dan postes. Mengingat keterbatasan waktu maka penggunaan google classroom sebagai media untuk menyampaikan materi, kegiatan, dan tugas, serta media untuk mengumpulkan tugas sangatlah efektif.

Penggunaan google classroom dalam proses penilaian sangat membantu untuk terlaksananya penilaian autentik. Dengan google classroom maka siswa dapat melakukan berbagai kegiatan pembelajaran seperti yang telah direncanakan sesuai dengan kompetensi dasar yang telah ditetapkan. . Keterbatasan waktu dan sarana yang ada di sekolah dapat teratasi karena siswa dapat melakukan kegiatan pembelajaran di lingkungan sekitar rumahnya. Dengan keaneka ragaman kegiatan pembelajaran maka penilaian sikap, pengetahuan, dan keterampilan dapat terakomodir dengan baik. Demikian juga dengan penilaian pre tes, proses, dan hasil semua dapat terlaksana karena keberadaan google classroom. Google classroom dapat menyimpan berbagai bentuk tugas sebagai bukti atas segala kegiatan yang telah dilakukan.

Pembelajaran temati menuntut siswa belajar untuk mengumpulkan informasi dengan pendekatan saintifik, memahami fenomena yang terjadi di dunia nyata dan mengkaitkan dengan apa yang dipelajari. Siswa mengetahui apa yang ingin mereka pelajari, menggunakan parameter waktu yang fleksibel, dan bertanggungjawab secara mandiri terhadap tugas. Penilaian autentik 
dapat membantu siswa untuk mengkonstruksi, mengorganisasi, menganalisis, mensintesis, menafsirkan, menjelaskan, dan mengevaluasi informasi untuk membentuk pengetahuan baru (Osman, Sarudin, Janan, \& Janan, 2016).

Berikut ini desain penilaian autentik untuk pembelajaran tematik IPA dan Bahasa Indonesia kelas VI yang dilakukan di SD Negeri Sidomulyo 05 Silo Kabupaten Jember. Diawali dengan menentukan kompetensi dasar dan indikator pembelajaran IPA dan Bahasa Indonesia, kemudian guru menentukan tujuan pembelajaran IPA Kelas VI SD, Setelah itu dilakukan kegiatan pembelajaran Tematik mata pelajaran IPA dan Bahasa Indonesia Kelas VI SD, dan tahap ketiga yaitu melakukan penilaian autentik dilakukan setelah kegiatan pembelajaran IPA Kelas VI SD. Berikut ini cara penilaian:

1) Penilaian Sikap dilakukan melalui observasi, penilaian diri, penilaian antar teman, dan jurnal.

a) Penilaian Observasi, (b) penilaian antar teman

2) Penilaian Pengetahuan dilakukan melalui tes tulis, tes lisan, dan penugasan.

- Tes Tulis : Bentuk soal isian singkat dan uraian

- Tes Lisan : Tanya Jawab

- Penugasan:

3) Penilaian Keterampilan dilakukan melalui penilaian kinerja, penilaian proyek, penilaian produk, penilaian portofolio, dan ketrampilan berdiskusi.

a) Penilaian Kinerja : a. dalam kegiatan diskusi (B.Indonesia) dan b.

demonstrasi mencangkok, mengenten, atau okulasi(IPA)

b) Penilaian Project : melalukan penelitian kecil dengan mengamati kegiatan petani kopi dalam melakukan kegiatan mengenten berupa dokumentasi kegiatan dan perkembangan tanaman

c) Penilaian Produk berupa laporan hasil pengamatan dan wawancara/browsing (IPA)

d) Penilaian Portofolio berupa rangkuman materi /review/kesimpulan/refleksi.
Untuk penilaian project dan produk: materi pokok dan petunjuk disampaikan melalui google classroom serta pengumpulan tugas siswa juga melalui google classroom.

e) Penilaian ketrampilan diskusi

$$
\text { Nilai }=\frac{\text { Jumlah Skor } x 10}{12}
$$

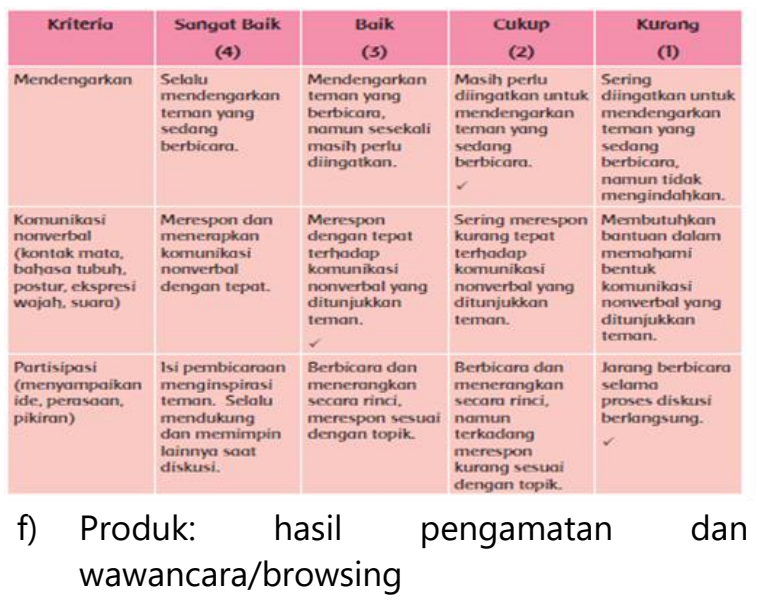

Daftar Periksa Tabel dan tulisan manfaat perkembangbiakan vegetatif

\begin{tabular}{|l|l|l|}
\hline \multicolumn{1}{|c|}{ Indikator Penilaian } & $\begin{array}{c}\text { Ada dan } \\
\text { Benar }\end{array}$ & Tidak Benar \\
\hline $\begin{array}{l}\text { Laporan memuat paling sedikit } 3 \text { nama } \\
\text { tumbuhan }\end{array}$ & & \\
\hline Tabel memuat cara perkembangbiakan & \\
\hline $\begin{array}{l}\text { Tabel memuat penjelasan cara } \\
\text { perkembangbiakan }\end{array}$ & \\
\hline $\begin{array}{l}\text { Manfaat perkembangbiakan secara } \\
\text { vegetatif ditulis dengan menyertakan } \\
\text { contoh }\end{array}$ & \\
\hline
\end{tabular}

Salah satu kelebihan Google Classroom menurut (Wicaksono \& Rachmadyanti, 2017) dibanding media sosial lainnya adalah terintegrasi dengan Google Drive sebagai penyimpanan file. Ketika guru mengunggah materi atau tugas, maka secara otomatis file materi atau tugas tersebut tersimpan di Google Drive. Sehingga guru tidak perlu khawatir kehilangan materi yang sudah disampaikan. Kekurangan Google Classroom diantaranya hanya bisa diakses menggunakan akun Google karena ingin menjaga keamanan dan kenyamanan pengguna dengan menerapkan berbagai sistem pembatasan akses pengguna.

Penelitian (Sukmawati, 2020) Google classroom merupakan metode yang tepat yang dapat digunakan dalam pembelajaran online yang 
melibatkan pendidik dan peserta didik secara aktif dalam proses pembelajaran. Metode ini dapat mempermudah pelaksanaan proses pembelajaran dimana pun peserta didik berada tidak terbatas pada ruang kelas dan buku yang tersedia. Sejalan dengan (Ramlah \& Awaru, 2020) bahwa penggunaan smartphone dalam proses belajar mengajar membawa dampak positif diantaranya: a) Peserta didik lebih mudah mendapatkan informasi-informasi yang terangkum dalam bentuk e-book, b) Peserta didik lebih awal untuk mengetahui materi pembelajaran, c) Peserta didik dibiasakan untuk berhadapan langsung serta memanfaatkan IT, d) Peserta didik bisa belajar mandiri, e) Guru memiliki variasi dalam mengajar, f) Memudahkan guru dalam pemeriksaan tugas.

Pemanfaatan Google Classroom diharapkan dapat membantu guru menyampaikan informasi secara tepat dan akurat kepada siswa serta dapat mengelola pembelajaran dengan baik (Soni \& Hafid, 2018). Aplikasi Google Classroom diharapkan pelaksanaan penilaian autentik akan menjadi lebih mudah dan lebih objektif serta dapat mengatasi kendala ruang dan waktu yang selama ini sering dijumpai dalam pembelajaran tematik. Hal ini sesuai dengan (Hapsari \& Pamungkas, 2019) bahwa dengan adanya media baru di era digital dalam sektor pendidikan maka dibutuhkan program pembelajaran campuran atau blended Learning.

Penelitian (Calista, 2019) menyatakan bahwa penilaian ranah afektif dan psikomotor belum secara optimal diterapkan oleh guru dan melakukan penilaian ranah kognitif. Sedangkan salah satu penekanan dalam kurikulum 2013 adalah penilaian autentik, sehingga selama proses pembelajaran guru juga melakukan penilaian dan bukan hasil akhirnya saja (Yubali, 2013). Untuk itu maka guru harus memahami tupoksinya, salah satunya adalah keterampilan melakukan penilaian hasil belajar peserta didik (Kunandar, 2015). Berdasarkan penelitian (Munawati, 2017) menyatakan bahwa penilaian autentik dilakukan guru melalui penilaian sikap dengan observasi, penilaian pengetahuan dengan tes tertulis, tes lisan dan penugasan, serta penilaian ketrampilan dengan tes praktik, produk dan proyek. Sehingga saran dari (Soebarna, Juditya, \& Gunawan, 2017) bahwa untuk penilaian ranah sikap (afektif) melibatkan guru bidang studi dan tidak difokuskan kepada guru pendidikan jasmani dengan demikian maka untuk ranah sikap dapat terjabarkan secara rinci. Berdasarkan penelitian-penelitian diatas maka diharapkan kendala-kendala yang dihadapi guru dalam melakukan penilaian autentik seperti yang ditekankan dalam Kurikulum 2013 dapat diatasi.

\section{Kendala yang Dihadapi dalam Pemanfaatan Google classroom}

Beberapa kendala yang ditemui saat pelaksanaan penilaian adalah adanya kesulitan siswa dalam mengaplikasikan google classroom antara lain:

1. kesulitan siswa dalam mengaplikasikan google classroom karena belum terbiasa menggunakannya sebab ini merupakan pengalaman pertama bagi mereka. Kesulitan guru dalam melakukan penilaian autentik karena waktu yang digunakan bisa lebih mencukupi bisa dibantu dengan pemanfaatan google classroom.

2. masih ada orang tua siswa yang belum bisa mengaplikasikan handphone android sehingga tidak bisa mendampingi siswa saat mengirimkan tugasnya melalui google classroom. Hal sejalan dengan penelitian (Rachmadyanti V. D., 2017) bahwa guru harus memberikan pemahaman kepada orang tua siswa supaya tidak terjadi kesalahpahaman dalam pelaksanaan pembelajaran menggunakan google classroom.

3. Tata tertib sekolah yang melarang siswa-siswi membawa handphone ke sekolah sedikit banyak mempengaruhi keleluasaan dalam pemanfaatan handphone dalam kegiatan pembelajaran,

4. Guru pun juga harus jeli terhadap berbagai kemungkinan penyalahgunaan handphone. Sehingga guru harus menentukan aturan yang jelas dalam penggunana handphone di sekolah. Penelitian (Sewang, 2017) menyatakan bahwa pemanfaatan google classroom di IAI DDI Polewali Mandar dapat diterima dan dikembangkan lebih lanjut meskipun masih membutuhkan pembenahan dari sisi ketersediaan sumber daya pendukung. 
Hasil Penelitian (Maryunita, 2017) dengan pemanfaatan teknologi dalam pembelajara maka dapat kembali meningkatkan minat peserta didik untuk belajar dan menumbuhkan budaya literasi. Sejalan dengan penelitian (Bahrul Ulum F. A., 2019) yang menyimpulkan bahwa penggunaan teknologi seperti smartphone dan tablet mempunyai banyak keuntungan dan dapat mendorong pengembangan literasi digital. Berdasarkan penelitian tersebut maka pemanfaatan google classroom diharapkan dapat meningkatkan budaya literasi digital.

Salah satu peran guru dalam menanamkan nilainilai kebaikan di era 4.0 adalah dengan memanfaatkan kecanggihan teknologi yang ada tanpa mengubah hal yang sudah ada salah satunya aplikasi google classroom yang di gagas oleh google (Maesaroh, 2018). Hal ini sejalan dengan penelitian (Sihotang, 2019) bahwa implementasi Media Pembelajaran E-learning Berbasis Google Classroom dapat meningkatkan motivasi belajar. Penggunaan Google Classroom berpengaruh positif dalam menunjang pembelajaran Bahasa. Hasil penelitian (Nurfalah, 2019) menyimpulkan bahwa Pengoptimalan fitur google classroom mempunyai dampak yang penting bagi pembelajaran di era revolusi industri 4.0(Bogdan \& Biklen, 2003), antara lain: (1) pembelajaran dilakukan secara online dengan memanfaatkan teknologi, (2) tidak terbatas oleh ruang dan waktu, (3) peserta didik terlibat langsung dalam proses pembelejaran yang memanfaatkan internet, (4) materi pembelajaran mudah diakses, (5) melatih keterampilan literasi data dan literasi teknologi. Google classroom merupakan layanan Google yang berbasis internet dengan sistem e-learning sehingga dapat dijadikan media pembelajaran yang efisien, efektif serta interaktif untuk menunjang pembelajaran berbasis teknologi.

\section{KESIMPULAN DAN SARAN}

Berdasarkan pemaparan pada hasil dan pembahasan maka dapat diambil kesimpulan bahwa pemanfaatan Google classroom dalam penilaian autentik di kelas VI SD Sidomulyo 05 Silo Kabupaten Jember meliputi: (1) membuat akun di Google Classroom ada enam langkah, (2) Penilaian autentik pembelajaran tematik Bahasa Indonesia dan IPA yang meliputi penilaian sikap dengan observasi dan penilaian antara teman, penilaian pengetahuan menggunakan tes tulis, lisan dan penugasan serta penilaian ketrampilan dengan menggunakan penilaian kinerja, proyek, produk, fortofolio dan ketrampilan diskusi, dan (3) kendala yang dihadapi dalam pemanfaatan Google Classroom adalah kesulitan siswa dalam mengaplikasikan google classroom karena belum terbiasa menggunakannya sebab ini merupakan pengalaman pertama bagi mereka dan masih ada orang tua siswa yang belum bisa mengaplikasikan handphone android sehingga tidak bisa mendampingi siswa saat mengirimkan tugasnya melalui google classroom. Tata tertib sekolah yang melarang siswa-siswi membawa handphone ke sekolah sedikit banyak mempengaruhi keleluasaan dalam pemanfaatan handphone dalam kegiatan pembelajaran serta Guru pun juga harus jeli terhadap berbagai kemungkinan penyalahgunaan handphone. Sehingga guru harus menentukan aturan yang jelas dalam penggunaan handphone di sekolah.

\section{DAFTAR PUSTAKA}

Aiman, U. (2016). Evaluasi Pelaksanaan Penilaian Autentik Kurikulum 2013; Studi Kasus di Madrasah Ibtidaiyah Negeri Tempel Sleman Yogyakarta. Jurnal Pendidikan Madrasah.

Andi, P. (2015). Menyusun Rencana Pelaksanaan Pembelajaran (RPP) Tematik Terpadu Implementasi Kurikulum 2013 Untuk SD/MI. In Kencana.

Astriyandi, A., Chotimah, U., \& Faisal, E. El. (2016). Kemampuan guru menerapkan penilaian autentik dalam pembelajaran ppkn. Jurnal Bhineka Tunggal Ika.

Bogdan, B. \& Biklen. (2003). Qualitative Research for Education. Boston: Allyn \& Bacon, Inc.

Calista, W. (2019). Pelaksanaan Penilaian Autentik Kurikulum 2013 Pada Pembelajaran Tematik Tema Sumber Energi Kelas III Di MI Negeri 1 Yogyakarta. MODELING: Jurnal Program Studi PGMI. https://doi.org/10.36835/modeling.v6i2. 450 
Hapsari, S. A., \& Pamungkas, H. (2019). Pemanfaatan Google Classroom Sebagai Media Pembelajaran Online di Universitas Dian Nuswantoro. WACANA: Jurnal Ilmiah Ilmu Komunikasi. https://doi.org/10.32509/wacana.v18i2.9 24

Karli, H. (2016). Penerapan Pembelajaran Tematik SD Di Indonesia. EduHumaniora | Jurnal Pendidikan Dasar Kampus Cibiru. https://doi.org/10.17509/eh.v2i1.2752

Kunandar. (2015). Penilaian Autentik (Penilaian Hasil Belajar Pesrta Didik Berdasarkan Kurikulum 2013. In Jurnal Evaluasi Pendidikan. https://doi.org/10.21009/JEP.022.05

Miles, Huberman, \& Saldana. (2014). Qualitative Data Analysis. California: Sage publication Inc.

Mulyadin, M. (2016). Implementasi Kebijakan Pembelajaran Tematik Terpadu Kurikulum 2013 di SDN Kauman 1 Malang dan SD Muhammadiyah 1 Malang. Jurnal Edutama.

Munawati, S. (2017). Pelaksanaan Penilaian Autentik Di Sekolah Dasar Negeri. Jurnal Pendidikan Guru Sekolah Dasar.

Osman, Z., Sarudin, A., Janan, D., \& Janan, D. (2016). Keberkesanan Pendekatan Autentik Dalam Meningkatkan Tahap Penulisan Karangan Pelajar. Pendeta: Jurnal Bahasa, Pendidikan Dan Sastera Melayu, 7, 142-155.

Permendikbud No 104. (2014). Salinan Lampiran Peraturan Menteri Pendidikan dan Kebudayaan Republik Indonesia Nomor 104 Tahun 2014 Tentang Penilaian Hasil Belajar oleh Pendidik Pada Pendidikan Dasar dan Pendidikan Menengah. Pedoman Evaluasi Kurikulum.

Prastowo, A. (2017). Menyusun Rencana Pelaksanaan Pembelajaran (RPP) Tematik Terpadu. In Kencana.
Puspita, H. J. (2016). Implementasi Pembelajaran Tematik Terpadu Pada Kelas Vb Sd Negeri Tegalrejo 1 Yogyakarta. Jurnal Pendidikan Guru Sekolah Dasar.

Ramlah, \& Awaru, A. O. T. (2020). Penggunaan smartphone dalam Proses Belajar Mengajar (Studi Kasus di SMA Negeri 4 Wajo). Jurnal Sosialisasi Pendidikan Sosiologi.

Soebarna, A., Juditya, S., \& Gunawan, G. (2017). Penilaian Autentik (Authentic Assesment) dalam Pembelajaran Penjas. JURNAL PENJAKORA. https://doi.org/10.23887/PENJAKORA.V $4 \mid 1.11757$

Soematri, M., \& Nana Syaodih. (2008). Perkembangan Peserta Didik. Jakarta: Universitas Terbuka.

Soni, S., \& Hafid, A. (2018). Optimalisasi Pemanfaatan Googleclassroom sebagai Media Pembelajaran di SMK Negeri 1 Bangkinang. Jurnal Pengabdian Untuk Mu Negeri, 2(1).

Ulum, B., Fantiro, F. A., \& Rifa'i, M. N. (2019). Pemanfaatan Google Apps di Era Literasi Digital Pada Siswa Sekolah Dasar. Lentera: Jurnal Pendidikan, 14(2), 22-31. https://doi.org/10.33654/jpl.v14i2.843

Wicaksono, V. D., \& Rachmadyanti, P. (2017). Pembelajaran Blended Learning Melalui Googgle Classroom di Sekolah Dasar.

Yubali, A. (2013). Penilaian Autentik Pada Kurikulum 2013. Seminar Nasional Implementasi Kurikulum 2013 Universitas Pelita Harapan, Karawaci, Tangerang, 742-749.

Zuhera, Y., Habibah, S., \& Mislinawati. (2017). Kendala Guru dalam Memberikan Penilaian Terhadap Sikap Siswa dalam Proses Pembelajaran Berdasarkan Kurikulum 2013 di SD Negeri 14 Banda Aceh. Ilmiah Pendidikan Guru Sekolah Dasar. 
